\title{
LEAD BIOSORPTION BY A BACTERIUM ISOLATED FROM INDUSTRIAL EFFLUENTS
}

\author{
SHRUTI MURTHY ${ }^{*}$, GEETHA BALI² AND SARANGI S.K. ${ }^{1}$ \\ 1Department of Microbiology and Biotechnology, Bangalore University, Bangalore - 560056, Karnataka, India. \\ 2Karnataka State Women's University, Bijapur 586101, Karnataka, India. \\ *Corresponding Author: Email- murthy.shruti@gmail.com
}

Received: March 24, 2012; Accepted: April 16, 2012

\begin{abstract}
An attempt was made to isolate microorganisms from the industrial effluents and to study their role in bioremediation of lead in selected industrial effluents. Sixty bacterial strains from the industrial effluent were isolated, purified, preliminarily identified and examined for their ability to uptake lead. Based on the minimum inhibition concentrations (MICs) of lead for the selected isolates, six strains were found to be most resistant isolates and amongst them one isolate showed maximum resistance to lead which was identified as Bacillus cereus. Scanning electron microscopic (SEM) photographs and Energy dispersive X-ray spectroscopy (EDS) signature of Bacillus cereus revealed that lead was adsorbed to the cell surface, confirming biosorption capacity of the bacteria.
\end{abstract}

Key words- Bacillus cereus, lead, biosorption, industrial effluent, EDS, SEM.

Citation: Shruti Murthy, Geetha Bali and Sarangi S.K. (2012) Lead Biosorption by A Bacterium Isolated from Industrial Effluents. International Journal of Microbiology Research, ISSN: 0975-5276 \& E-ISSN:0975-9174, Volume 4, Issue 3, pp.-196-200.

Copyright: Copyright@2012 Shruti Murthy, et al. This is an open-access article distributed under the terms of the Creative Commons Attribution License, which permits unrestricted use, distribution, and reproduction in any medium, provided the original author and source are credited.

\section{Introduction}

Non-essential metals are generally of low abundance in the biosphere and should therefore not compete with specific transport systems for essential elements. However, due to industrial activities and the resulting changes in global elemental distribution and pollution of aquatic and terrestrial habitats, microorganisms are increasingly being exposed to potentially toxic conditions which may inhibit enzymatic activities, disrupt membrane function and damage nucleic acids in microorganisms [1]. At the community level, metals can decrease overall metabolic activity, diversity and total numbers of cells [2]. The effects of these contaminants in different populations have been reported [3]. To overcome these toxic conditions microorganisms may tend to respond, using a variety of strategies that ensure their survival and reproduction.

Microbial metal resistance mechanisms include precipitation of metals as phosphates, carbonates and sulfides; metal volatilization by methyl or ethyl group addition; physical exclusion by elec- tronegative components in membranes and extracellular polymeric substances (EPS); energy dependent metal efflux systems; and intracellular sequestration with low molecular weight, cysteine-rich proteins $[4,5]$. In general, while microbial metal resistance includes a variety of strategies to deal with toxic metal concentrations in the environments [6], these strategies are aimed at either to prevent entry of the metal into the cell or to actively pump the metal out of the cell. Such resistance can be divided into two classes: metal dependent and metal-independent.

The study of the interactions between heavy metals and microorganisms has been specially focused on bacterial transformation and conversion of metallic ions by reduction in different polluted environments [7], the selection of metal-resistant microorganisms from polluted environments [8], and the use of resistant microorganisms as indicators of potential toxicity to other forms of life [9] as well as on mechanisms, determinants and genetic transfer of microbial metal-resistance [10]. 
The removal of lead from contaminated wastewaters using bacteria (Pseudomonas sp., Chryseomonas luteola and Bacillus circulans) has been reported by several authors [11-13], who attempted to investigate the ability of lead biosorption by lead resistant bacteria isolated from an industrial effluent.

Tolerance and removal of toxic metal ions have been studied in bacteria [14-20], cyanobacteria [21, 22], algae [23-26] and fungi [27-29]. Eccles, [30] has opined that the microbiological detoxification of polluted water is economical, safe and sustainable. Grampositive bacteria are known to possess high metal sorption capacities. The ability of the cell wall of Bacillus subtilis to interact with different heavy metals has been much studied [31].

Some metal- microbe interactions, where accumulation by the biomass leads to removal from the external environment, are of current biotechnological interest, for both the recovery of valuable metals and the detoxification of polluted effluents.

Lead, the most common metal found as byproducts of processes such as mining and ore processing, as well as burning of fossil fuels, is less studied than other metals. Though lead has no known biological function, it is highly toxic and accumulates in humans [32]. Because of its toxic effects on human life, lead was selected for this work. Recently, we have isolated a gram positive bacterium (Bacillus cereus) from an industrial effluent sample with the ability to grow in high concentrations of lead.

The aim of this work is to identify this bacterium and to determine whether the strain's ability to tolerate such high concentrations of lead is from an ability to accumulate lead externally or internally in intracytoplasmic inclusions.

\section{Materials and Methods \\ Water sample}

The water samples were collected from Vrishbhavathi River flowing through the Peenya Industrial area, Bangalore (Karnataka, India). Subsurface water samples were collected using water sampler at four different locations and subjected to physico-chemical analysis.

\section{Isolation and identification of bacteria from industrial effluent samples}

$100 \mathrm{ml}$ of water samples were collected and passed through a sterile membrane filter of $0.45 \mu \mathrm{m}$ pore size, and then the membrane was aseptically placed on the surface of tryptone glucose extract agar medium supplemented with $100 \mathrm{mg} / \mathrm{l}$ of lead for isolation of bacteria. Plates were incubated at $37^{\circ} \mathrm{C}$ for $24 \mathrm{hrs}$. The bacteria that grew were preliminarily identified according to the key of Bergey's Manual of Determinative Bacteriology [33] after carrying out staining and biochemical tests.

\section{Determination of heavy metal ion content.}

The heavy metal ion content in collected water samples and in broth media used during the experiments were determined using the Atomic Absorption Spectrophotometer (Electronic Corporation of India Ltd., model ElementAS AAS4139) according to the procedure of Shouxin and Ling [34].

\section{Isolation and identification of most resistant isolates}

Lead stock solution was prepared from lead nitrate. Tryptone glucose extract agar plates were inoculated with $1 \mathrm{ml}$ aliquots of $24 \mathrm{hr}$ old cultures of six bacterial isolates which showed faster growth on $100 \mathrm{mg} / \mathrm{l}$ concentration of lead. After solidification, different concentrations of lead $(50,100,150,200,300,400$ and $500 \mathrm{mg} / \mathrm{l})$ were inoculated in wells and the plates were then incubated for $48 \mathrm{hrs}$ at $30^{\circ} \mathrm{C}$. Diameter of inhibition zones were measured (in $\mathrm{mm}$ ) to determine the most resistant isolate. The isolate showing highest MIC was sent for identification at Bangalore Genei, Bangalore.

\section{Bacillus cereus resistance to divalent metal ions in TYG me- dia}

Heavy metal ion resistance testing was done by determining the minimal inhibitory concentrations (MICs) of the divalent metals ions $\left(\mathrm{Zn}^{2+}, \mathrm{Cu}^{2+}, \mathrm{Co}^{2+}\right.$ and $\left.\mathrm{Ni}^{2+}\right)$, in TYG media (per liter of deionized water). Analytical grade salts of $\mathrm{ZnCl}_{2}, \mathrm{CuCl}_{2} .2 \mathrm{H}_{2} \mathrm{O}, \mathrm{Ni}-$ $\mathrm{Cl}_{2} .6 \mathrm{H}_{2} \mathrm{O}$ and $\mathrm{CoCl}_{2} .6 \mathrm{H}_{2} \mathrm{O}$ were dissolved in deionized water to form $10,000 \mathrm{mg} / \mathrm{l}$ stock solutions, filter sterilized using $0.2 \mu \mathrm{m}$ pore -size Millipore filters. The plates were seeded with $1.0 \mathrm{ml}$ aliquots of 24 hours old cultures of Bacillus cereus. After solidification different concentrations of copper, nickel, zinc and cobalt were inoculated in wells and plates were then incubated for $48 \mathrm{hrs}$ at $30^{\circ} \mathrm{C}$ Diameters of inhibition zones were measured in $(\mathrm{mm})$ to determine the resistance of Bacillus cereus towards divalent metal ions. Triplicates were prepared for each concentration.

\section{SEM and EDS analysis}

$10 \mathrm{ml}$ broth culture of the most resistant isolate was centrifuged at $10,000 \mathrm{rpm}$ at $4^{\circ} \mathrm{C}$ for 5 mins. The pelleted cells were washed twice with $0.1 \mathrm{M}$ phosphate buffer $(\mathrm{pH} 7)$ and were fixed overnight in $2 \%$ glutaraldehyde. The cells were washed again with phosphate buffer and then with distilled water, before further processing. The cells were dehydrated through a series of different concentrations ( $10 \%$ to absolute) of ethanol by holding them in each concentration for half an hour. The SEM and EDS analysis of the cells were carried out at Geological Survey of India, Kolkata to determine the loci of lead accumulation in the cells.

\section{Results \\ Physico-chemical analysis of water sample}

The concentrations of heavy metals in three different water samples (Table.1) revealed that the tested metal ions were within permissible concentrations except for lead (sample $1: 0.07 \mathrm{mg} / \mathrm{l}$ and sample 2\&3:0.06 mg/l).

\section{Isolation and identification of bacteria from industrial effluent samples}

Sixty bacterial strains were isolated from the water samples. The Gram characteristics of the isolated colonies are summarized in Fig.1. Forty seven isolates were Gram positive, with thirty eight Gram positive rods and nine Gram positive cocci, and thirteen Gram negative isolates included ten Gram negative rods and three Gram negative cocci.

\section{Isolation and identification of most resistant isolates}

The Minimum Inhibition Concentrations (MICs) of sixty isolates for lead concentrations $(50,100,150,200,300,400$ and $500 \mathrm{mg} / \mathrm{l})$ revealed that six (isolate 1, 2, 3, 4, 5 and 6 ) out of sixty isolates were able to tolerate a high concentration of lead $(500 \mathrm{mg} / \mathrm{l})$. The MIC 
Table 1- Phisico-chemical analysis of the three water samples collected from Vrishabhavathi river

\begin{tabular}{|c|c|c|c|c|}
\hline Tests & $\begin{array}{l}\text { Limits ( For } \\
\text { industrial } \\
\text { effluents dis- } \\
\text { charged on } \\
\text { land for irriga- } \\
\text { tion) }\end{array}$ & Sample 1 & Sample 2 & Sample 3 \\
\hline Colour & & Pale Grey & Pale yellow & Pale Grey \\
\hline Odour & & Objectionable & Slight & Objectionable \\
\hline $\mathrm{pH}$ & $5.5-9.0$ & & 7 & \\
\hline $\begin{array}{l}\text { Total chlorides, as } \mathrm{Cl} \\
\mathrm{mg} / \mathrm{L}\end{array}$ & $\operatorname{Max} 600$ & 137.7 & 110.2 & 137.7 \\
\hline $\begin{array}{l}\text { Total suspended } \\
\text { solids, mg/L }\end{array}$ & $\operatorname{Max} 200$ & 376 & 184 & 325 \\
\hline $\begin{array}{l}\text { Total dissolved sol- } \\
\text { ids, mg/L }\end{array}$ & Max 2100 & 700 & 476 & 600 \\
\hline $\begin{array}{l}\text { Biochemical oxygen } \\
\text { demand (at } 20^{\circ} \mathrm{C} \text { for }\end{array}$ & $\operatorname{Max} 100$ & 252 & 24 & 195 \\
\hline 5 days), $\mathrm{mg} / \mathrm{L}$ & & & & \\
\hline $\begin{array}{l}\text { Chemical oxygen } \\
\text { demand, } \mathrm{mg} / \mathrm{L}\end{array}$ & $\operatorname{Max} 250$ & 521 & 76 & 521 \\
\hline $\begin{array}{l}\text { Dissolved oxygen, } \\
\mathrm{mg} / \mathrm{L}\end{array}$ & & & 1.34 & \\
\hline Oil and Grease, $\mathrm{mg} / \mathrm{L}$ & L Max 10 & $<1.0$ & $<1.0$ & $<1.0$ \\
\hline Conductivity & & 1.84 & 1.3 & 1.71 \\
\hline Cyanide as $\mathrm{CN}, \mathrm{mg} / \mathrm{L}$ & $L \operatorname{Max} 0.2$ & $<0.01$ & $<0.01$ & $<0.01$ \\
\hline $\begin{array}{l}\text { Total sulphates, as } \\
\mathrm{So}_{4}, \mathrm{mg} / \mathrm{L}\end{array}$ & $\operatorname{Max} 1000$ & 41 & 26 & 30 \\
\hline Boron, as B, mg/L & $\operatorname{Max} 2.0$ & $<0.1$ & $<0.1$ & $<0.1$ \\
\hline Arsenic, as As, mg/L & $\operatorname{Max} 0.2$ & $<0.01$ & $<0.01$ & $<0.01$ \\
\hline Nickel, as Ni, mg/L & $\operatorname{Max} 3.0$ & $<0.01$ & $<0.01$ & $<0.01$ \\
\hline Copper, as $\mathrm{Cu}, \mathrm{mg} / \mathrm{L}$ & $\operatorname{Max} 3.0$ & $<0.05$ & $<0.05$ & $<0.05$ \\
\hline Zinc, as Zn, mg/L & $\operatorname{Max} 5.0$ & $<0.09$ & $<0.04$ & $<0.05$ \\
\hline Lead, as $\mathrm{Pb}, \mathrm{mg} / \mathrm{L}$ & $\operatorname{Max} 0.05$ & 0.07 & 0.06 & 0.06 \\
\hline
\end{tabular}

studies further revealed that the increase in clear zone (diameter) of the six isolates were directly proportional to the metal ion concentration. The MICs of lead ions against the selected six isolates were determined using increasing concentrations of lead (100, $200,300,400,500$ and $1000 \mathrm{mg} / \mathrm{l})$. The results have shown that only one isolate (out of the six) was able to tolerate $1000 \mathrm{mg} / \mathrm{l}$ of lead (Fig 2 and 3). Identification of the most resistant strain (isolate 6) was confirmed as Bacillus cereus (GenBank Accession Number: EF488087) at Bangalore Genei, Bangalore based on $16 \mathrm{~S}$ rDNA data.

\section{MIC of lead in Bacillus cereus}

The MIC of lead was determined using increasing concentrations of Lead (100 to 10,000 mg/l). The result depicted in Fig. 3 revealed that MIC of Lead for Bacillus cereus (Isolate 6) was at $1000 \mathrm{mg} /$, where as the other five bacterial isolates showed less MICs.

\section{Bacillus cereus resistance to divalent metal ions in TYG me- dia}

The Minimum Inhibition Concentration (MIC) of Bacillus cereus for different metals ions $\left(\mathrm{Zn}^{2+}, \mathrm{Cu}^{2+}, \mathrm{CO}^{2+}\right.$ and $\left.\mathrm{Ni}^{2+}\right)$ was determined using increasing concentrations of metal ions $(100,500,1000$, 1200 and $1500 \mathrm{mg} / \mathrm{l}$ ). Figure 4 shows MICs of the bacterial isolate in the TYG media. The isolate showed different degrees of resistance to the heavy metals. The isolate showed resistance to $\mathrm{Ni}^{2+}$ and $\mathrm{Cu}^{2+}$ at concentrations below $1000 \mathrm{mg} / \mathrm{l}, \mathrm{CO}^{2+}$ at concentrations below $100 \mathrm{mg} / \mathrm{l}$ and $\mathrm{Zn}^{2+}$ at concentrations below $500 \mathrm{mg} / \mathrm{l}$ when grown for $48 \mathrm{~h}$.

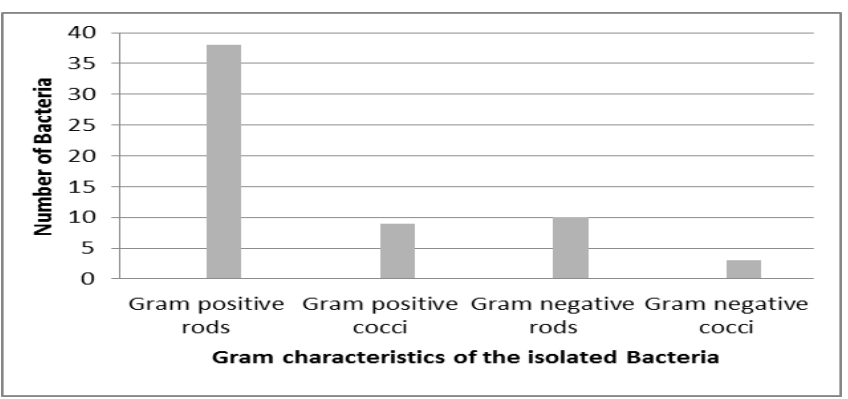

Fig. 1- Gram characteristics of the isolated bacteria from the three water samples.

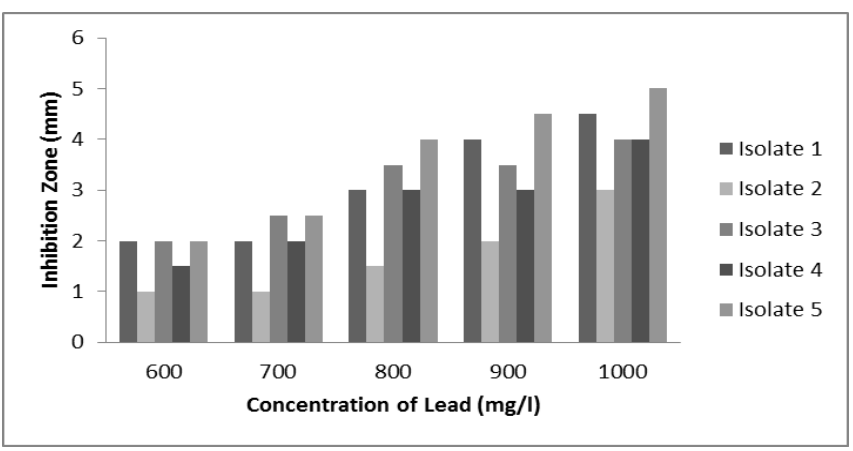

Fig. 2- MIC of Lead in isolates 1, 2, 3, 4 and 5

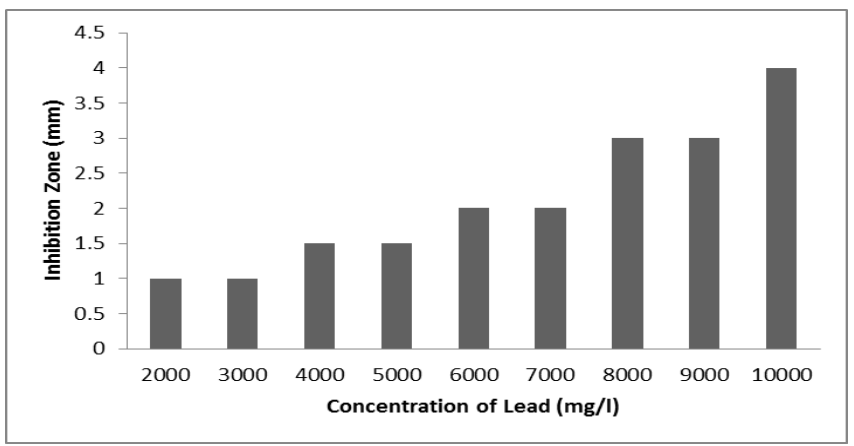

Fig. 3- MIC of Lead in isolates 6.

The results suggest that in TYG medium, the isolate was most resistant to $\mathrm{Ni}^{2+}$ and $\mathrm{Cu}^{2+}$, moderately resistant to $\mathrm{Zn}^{2+}$ and least resistant to $\mathrm{Co}^{2+}$. It was interesting to observe that although $\mathrm{Co}^{2+}$ was the most toxic metal to the isolate, it showed resistance below $100 \mathrm{mg} / \mathrm{l}$, beyond which the growth was completely inhibited.

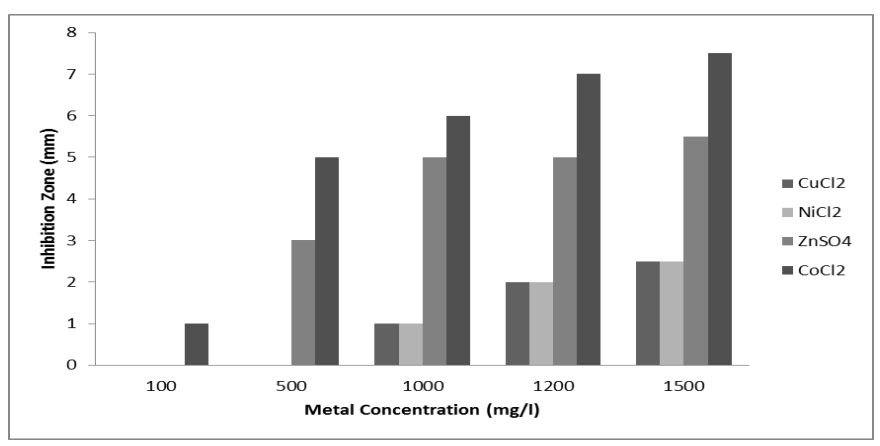

Fig. 4- Bacillus cereus MIC to divalent metal ions copper, nickel, zinc and cobalt 


\section{SEM and EDS analysis}

The SEM photographs and EDS signatures (fig 5 and fig 6) revealed that lead was mostly entrapped in the extracellular polymeric substances (EPS) in Bacillus cereus.

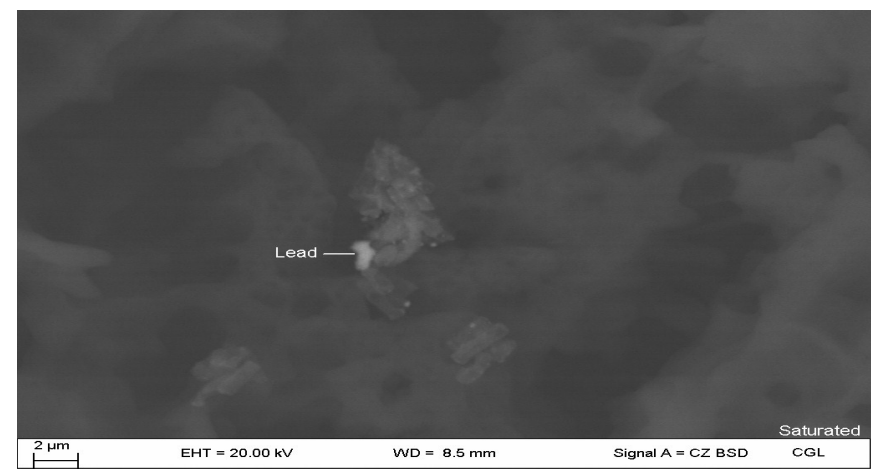

Fig. 5- SEM photograph of Bacillus cereus grown in 500mg/l lead

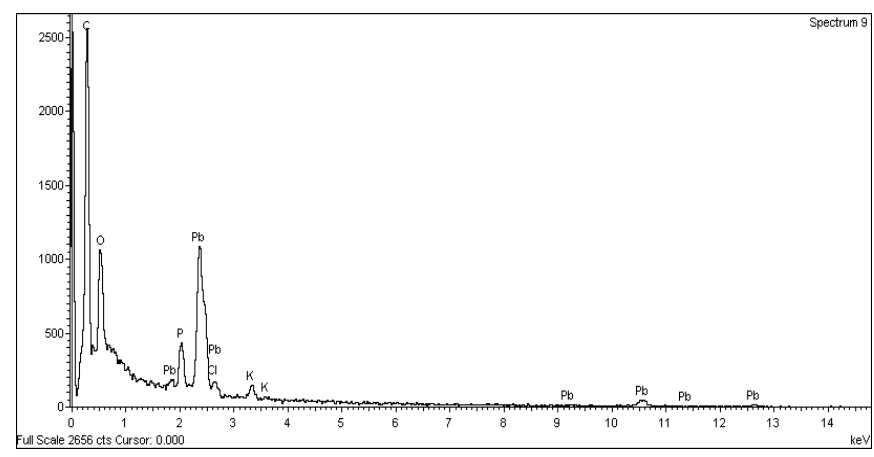

Fig. 6- EDS signature showing presence of lead $(500 \mathrm{mg} / \mathrm{l})$ in the cell of Bacillus cereus

\section{Discussion}

The growing industrialization and modern agricultural practices that have spread worldwide have adversely affected the ecosystem. These practices leave persistent toxic metals and organic pollutants in the surroundings, which tend to accumulate and deteriorate the environment [32]. Contamination of heavy metals in the environment is a major global concern because of their toxicity and threat to human life and environment.

Studies on the concentrations of heavy metals in three different water samples revealed that the tested metal ions were within permissible concentrations except for lead. Thus these water samples were subjected to isolation of lead resistant bacterial isolates.

The mechanisms by which ions bind to the cell surface include electrostatic interactions, van der Waals forces, covalent bonding, redox interactions and extracellular precipitation, or a combination of these processes. The negatively charged groups (carboxyl, hydroxyl and phophoryl) of the bacterial cell wall adsorb metal cations, which are then retained by mineral nucleation.

The MICs of metal ions against the selected isolates using increasing concentrations of lead $(100,200,300,400,500$ and $1000 \mathrm{mg} / \mathrm{l})$ revealed that only one isolate was able to tolerate high concentrations $(1000 \mathrm{mg} / \mathrm{l})$ of lead. This varying response of selected bacteria might be due to the differences in their cell wall composition or due to variations in resistance mechanisms. Identification of the most resistant strain was confirmed as Bacillus cereus. Bacillus cereus showed varying resistance towards divalent metal ions in the order of $\left(\mathrm{Ni}^{2+}>\mathrm{Cu}^{2+}>\mathrm{Zn}^{2+}>\mathrm{Co}^{2+}\right)$. Rajendran et al, [32] has opined that the biosorption studies of $U, Z n$, $\mathrm{Pb}, \mathrm{Cd}, \mathrm{Ni}, \mathrm{Cu}, \mathrm{Hg}$, Th, Zn, Cs, Au, Ag, Sn and Mn, showed that the extent of sorption varies markedly with the metal as well as with the microorganisms.

Various mechanisms have been postulated for the development of metal resistance in microorganisms [35-37]. However in general, all these strategies are found either to prevent the entry of metal ions into the cell or to actively pump out the metal ions from the cell [6].

The SEM photographs and EDS signatures (fig 3 and fig 4) revealed that lead was mostly entrapped in the extracellular polymeric substances (EPS) in Bacillus cereus. This could be due to efflux, commonly seen in bacteria as a detoxification measure as reported earlier [38]. Bacteria grown in medium without lead showed no signals of lead in the EDS analysis. Among bacteria, the Bacillus sp. has been identified as having a high potential for metal sequestration and also used in commercial biosorbent preparations [39]. The walls of the gram positive bacteria are efficient metal chelators and in Bacillus sp. the caboxyl group of glutamic acid of peptidoglycan is the major site for metal deposition. Teichoic and Teichronic acids are important binding sites in Bacillus sp [40]. These extracellular polymers have been implicated in nutrient storage, adhesion, and in barrier formation against environmental toxicants, including metals [41, 42]. Specifically, uronic acids and sulphate groups present in EPS may interact with various metals thereby immobilizing them [43]. The polarization data in conjunction with the TEM results infer that lead was sequestered in the polymeric layer. The reactions between exopolymers and metals are thought to involve specific ionic interactions.

\section{Conclusion}

From the results, it can be concluded that Bacillus cereus can tolerate higher concentrations of lead by extracellular biosorption. Hence it is imperative that the Bacillus cereus could be considered as a promising candidate for the removal of lead from wastewaters.

\section{Acknowledgment}

This work was financially supported by ISRO, Department of Space (DOS), Govt. of India. The first author thanks the DOS for the JRF. The authors thank the Department of Microbiology and Biotechnology, Bangalore University, Bangalore for providing laboratory facilities.

\section{References}

[1] Foster T.J. (1983) Microbiol. Rev., 47, 361-409.

[2] Roane (1998) Microb. Ecol., 37, 218-224.

[3] Maldonado J., Diestra E., Huang L., Domènech A.M., Villagrasa E., Puyen Z.M., Duran R., Esteve I. and Solé A. (2010) Ann. Microbiol., 60, 113-120.

[4] Gadd G.M. (1990) Microbiology of extreme environment, 178210.

[5] Silver S. (1998) J. Indust. Microbiol. Biotechnol., 20, 1-12.

[6] Roane T.M., Pepper I.L. and Miller R.M. (1996) Bioremediation: principles and applications, 312-340.

[7] Chang J.S., Hong J., Ogunseitan O.A. and Olson H.B. (1993) 
Biotechnol. Prog., 9, 526-532.

[8] Hiroki M. (1994) J. Soil Sci. Plant Nutr., 40, 515-524.

[9] Doelman P., Jansen E., Michels M. and Van Til M. (1994) Biol. Fert. Soils, 17, 177-184.

[10]De Rore H., Top E., Houwen F., Mergcay M. and Verstraete W. (1994) FEMS Microbiol. Ecol., 14, 263-273.

[11]Leung W.C., Wong M.F., Chua H., Co W., Yu P.H.F. and Leung C.K. (2000) Water Sci. Technol., 41 (12), 233-240.

[12]Azza A. Abou Zeid, Wesam A. Hassanein, Hedayat M. Salama and Ghada A.A. Fahd (2009) J. Appl. Sci. Res., 5 (4), 372383.

[13]Khanafari A., Eshghdoost S. and Mashinchian A. (2008) Iran. J. Environ. Health Sci. Eng ., 5 (3),195-200.

[14]Silver S. and Phung L.T. (2005) J. Ind. Microbiol. Biotechnol., 32, 587-605.

[15]Deveci H., Akcil A. and Alp I. (2004), Hydrometallurgy, 73, 293 $-303$.

[16]Yilmaz E.I. (2003) Res. Microbiol., 154, 409-415.

[17]Shakoori A.R. and Muneer B. (2002) Folia Microbiol., 47, 4350.

[18]Cervantes C., Campos Garcia J., Devars S., Gutierrez Corona F., loza Tavera H., Torres Guzman J. C. and Moreno Sanchez R. (2001) FEMS Microbiol. Rev., 25, 335-347.

[19]Ledin M. (2000) Earth Sci. Rev., 51, 1-31.

[20]Volesky B. and Holan Z.R. (1995) Biotechnol. Prog., 11, 235250.

[21]Wang W.X., Del R.C. and Hong H. (2005) Environ. Toxicol. Chem., 24, 161-169.

[22] Inthorn D., Nagase H., Isaji Y., Hirata K. and Miyamoto K. (1996) J. Ferment. Bioeng., 82, 580-584.

[23]Feng D. and Aldrich C. (2004) Hydrometallurgy, 73, 1-10.

[24]Torricelli E., Gorbi G., Pawlik- Skowronnska B., Sanita D.L. and Corradi M.G. (2004) Aquat. Toxicol. 68, 315-323.

[25]Davis T.A., Volesky B. and Mucci A. (2003) Water Res., 37, 4311-4330.

[26]Rehman A. and Shakoori A.R. (2001) Bull. Environ. Contamin. Toxicol., 66, 542-547.

[27]Pas M., Milacic R., Draslar K., Pollak N. and Raspor P. (2004) Biometals, 17, 25-33.

[28]Yan H. and Viraraghavan T. (2003) Water Res., 37, 44864496.

[29]Holan Z.R. and Volesky B. (1995) Appl. Biochem. Biotechnol., 53, 133- 146.

[30]Eccles H. (1995) Int. Biodeter. Biodegr., 35, 5-16.

[31]Tunali S., Çabu A. and Akar T. (2006) Chem. Eng. J., 115, 203- 211.

[32]Rajendran P. and Gunasekaran P. (2007) Microbial Bioremediation, 181-190.

[33]Kreig N.R. and Holt J.G. (1984) Bergey's Manual of Systematic Bacteriology, 1 (1).

[34]Ren S. and Gao L. (1995) J. Autom. Chem., 17(3), 115-118.

[35]Hughes M.N. and Poole R.K. (1989) Metals and microorganisms.

[36]Gadd G.M. (1990) Experientia, 46, 834- 840.

[37]Roane T.M. and Kellogg S.T. (1996) Can. J. Microbiol., 42, 593- 603.

[38]Nies D.H. (1999) Appl. Microbiol. Biotechnol., 51, 730- 750.

[39]Brierley J.A., Brierley C.L. and Goyak G.N. (1986) Fundamen- tals and Applied Biohydrometallurgy, 291-304.

[40]llhan S., Nourbakhsh M.N., Kilicarslan S. and Ozdag H. (2004) Turkish J. Biotechnol., 2, 50-57.

[41]Francis A.J. (1990) Experientia, 46, 840- 851.

[42]Decho A.W. (1994) Microbial mats, 215- 219.

[43]Stal L.J. (2000) The ecology of cyanobacteria, 61-120. 